УАK (UDC) 141.319 .8

DOI: 10.26565/2226-0994-2020-63-1

Nataliia Zahurska

\title{
POSTHUMAN IN A SECRET S/P(L)ACE
}

In this article posthumanistic aspects of the problem of secret $\mathrm{s} / \mathrm{p}(\mathrm{l})$ ace, i. e. both spaces and place were researched. Differentiation of a space and a place, a secret and a mystery was made. A manifold of a conception of secrecy (mysteriousness, veiling, ciphered, etc.) from a tendency to keep a secret of $\mathrm{s} / \mathrm{p}(1)$ ace carefully to claim to demystify a place completely is investigated. Philosophy, philosophical anthropology especially, appears as geophilosophy, human geography in this case. Thus a conceptualizing human being is surveying in a friendship with a landscape, $\mathrm{s} / \mathrm{p}(\mathrm{l})$ ace. The importance of natural elements (water, air, fire, etc.) for secret s/p(l)ace has been demonstrated. Of particular actuality to this study is the appeal to the current concept of the atmosphere, which is weakly perceptible, but is influential. The relationship between a secret $\mathrm{s} / \mathrm{p}(\mathrm{l})$ ace and a secret self, such as a freak, Secret Santa, etc., was traced. A distinction is made between a secret $\mathrm{s} / \mathrm{p}(\mathrm{l})$ ace and a non-place like moving place with a discourse, place of surveying. The importance of a secret $\mathrm{s} / \mathrm{p}(\mathrm{l})$ ace for the formation of a post-body in a situation where the body as such is lost is shown. The importance of psychoanalytic and psychogeographic conceptualization of a secret $\mathrm{s} / \mathrm{p}(\mathrm{l})$ ace is also demonstrated. They are adjoined by the consideration of space concerning boredom as stabilization of pleasure in the habitual and comfortable, good banality, a bliss from the side of pleasure. The significance of the secret $\mathrm{s} / \mathrm{p}(\mathrm{l})$ ace is asserted in conditions when the city plays not only a conjunctive, connecting, but also a disjunctive, disconnecting role. A conclusion is made about a secret $\mathrm{s} / \mathrm{p}(\mathrm{l})$ ace as a posthuman place of a place, a place-without-place with a secret of mystery. The study was carried out on the material of actual culture (literature, cinema, architecture, and design, etc.), as well as life practices. This corresponds to the Deleuzian statement about the intersection of concept, prospectus and affect. The study also involved speculative realism, speculative posthumanism, and other related conceptions.

Keywords: secret s/p(l)ace, space, place, posthuman, a human being.

There is a secret place I like to go

There is a secret place that I belong A wonderland, a myth, the great unknown

There is a place I like to go

The Grus. A Secret Place

A degree of problem development of secret $\mathrm{s} / \mathrm{p}(\mathrm{l})$ ace, i. e. both spaces and place, of a human being has a reach philosophical heritage. So Martin Heidegger signs it as veiling - unveiling passing. However, he has hardly ever taken into account a thought that doesn't think, a thought as such in comparison with Michel Foucault, who explored a passing of outside-interior as a possibility of an appearance of multiple heterotopias of deviance or heterogeneity, in the words of Steve Pile, as diversification. In any case, if a time is considering as the key to dynamics, then $\mathrm{s} / \mathrm{p}(\mathrm{l})$ ace as the key to statics up to boredom and routine even on passages in the comprehension of Walter Benjamin and Siegfried Kracauer.

In contemporary philosophy, the attempt to living up, re-animate a landscape is to make the sense to place and the politics of space, which intertwine. However, in this case, the authenticity of $\mathrm{s} / \mathrm{p}(\mathrm{l})$ ace, its secrecy is losing as in the conception of Henri Lefebvre, who considers space as a shape of social reproduction, attempt to constrain and limit economic and political access to space. As well as Henry Lefebvre, Tim Cresswell suggests demystify a place and free it from any mysteries as traps. It seems developing of Walter Benjamin's approach, contradicting of the spatial and the mystical experiences. In this context, a space and a place are

(C) Zahurska N. V., 2020. 
been almost identifying and the difference between them is purely conditional. «Space, then, has been seen in distinction to place as a realm without meaning - as a "fact of life" which, like time, produces the basic coordinates for human life. When humans invest meaning in a portion of space and then become attached to it in some way (naming is one such way) it becomes a place» [Cresswell, 2004, p. 10].

Meanwhile, Tim Cresswell himself determines human geography both as a study of places and philosophy. Thus, he adjoins the tradition of Yi-Fu Tuan, who understood a place as a closed and humanized space. He also, unlike Walter Benjamin, compared space with movement, but place with pauses and stoppings between spaces. This tradition gives a possibility to Michel de Certeau and Marc Augé to inquire about the end of a place and conceptualize a non-place. As Dolores Hayden affirms that in a contemporary culture nobody «knows one's place» because a place in a social and cultural sense doesn't exist anymore. It seems one of the reasons for posthumanism actualizing. Instead, distinguishing by Yi-Fu Tuan place as a biological response to the surrounding physical environment engages a sensorium of a human being up to feeling an essence of places. Such an experience of place is unique, authentic and to be consistent secret.

Gilles Deleuze and Felix Guattari attract attention to the significance of the concept of cipher including meanings secret code and initials, i. e. combination of surveying events, which provide philia. Given that in Deleuzian understanding philosophy always is a geophilosophy, replacing genealogy with a geology and history with becoming in a stratigraphic time. Concept of secret $\mathrm{s} / \mathrm{p}(\mathrm{l})$ ace correlates with a concept of folding, in which a pledge of an event is a special object. If in the agapic neighborhood human beings partially indiscernible, philiastic friendship as a pretense includes elements of agon and again and again being traversed by a fissure like a fisherman, who is finding himself in the open sea instead of the port as he thinks. In words of Timothy Morton, he veers in en-vironment. As a last resort, it's talked about movable bridges as a metaphor for deterritorization and reterritorialization in one plane of composition. In this context affects as nonhuman becomings of a human being and percepts as nonhuman landscapes of nature consist and as an effect of this «the landscape sees» [Deleuze \& Guattari, 1994, p. 169].

So, veering in en-vironment is realizing in all three versions: variations of concepts, varieties of sensations and variables of prospects. Art in this relation combines with philosophy for giving too tender flesh of concept and plane of immanence, in general, some bone or skeletal structure of art sensation and plane of composition in general. However, a sensation with its monumentality also situates in a state of pretense with a concept with its eventuality. A better compromise in this situation is a refrain, ritournelle, tra-la-la-la as a kind of monument. "The great refrain arises as we distance ourselves from the house, even if this is in order to return, since no one will recognize us any more when we come back» [Deleuze \& Guattari, 1994, p. 191]. It is because we return as a nonhuman or posthuman, saturated with melodic air. So the metaphor of water as initiation is complimented by the metaphor of air, atmosphere, ambiance as freedom also often presenting in describing a secret $\mathrm{s} / \mathrm{p}(\mathrm{l})$ aces.

The novelty of this article largely due to the appeal to the concept of atmosphere, one of the key in the contemporary intellectual context and correlating with more often used earlier ambiance. "One has the impression that "atmosphere" is meant to indicate something indeterminate, difficult to express, even if it is only in order to hide the speaker's own speechlessness» [Böhme, 1993, p. 113]. Gernot Böhme matches the atmosphere with the aura of Walter Benjamin, more of Theodor Adorno and so forth. He notes, that atmosphere may indicate embarrassment as well as emphasis and signifies space, nature or self. The latter in this case is especially relevant since it is the human being who determines the secrecy of the $\mathrm{s} / \mathrm{p}(\mathrm{l})$ ace and through this can even become secret itself.

This article aims to track this issue in a contemporary context, for example, the game in a Secret Santa as a secret self often practices. During this game, the self to whom the gift was presented must guess who prepared or purchased it. For example, this game great described in a novel The Perks of Being a Wallflower by Stephen Chbosky. Although wallflower can mean 
demure self, lonely girl or idle ship, the secret $\mathrm{s} / \mathrm{p}(\mathrm{l})$ ace here situated on a hill with an excellent view and airy atmosphere, ambiance as well as a crucial scene with the wind in a moving car, leaving the tunnel. The character of this novel are also great examples of secret selves, freaks as spatial reterritorialized new mutants, monsters, deviants with a secret self [Fiedler, 1978]. When since the 1960s abnormality becomes entertainment and freak out, real freaks or postfreaks such as characters of The Perks of Being a Wallflower tend to trueness in their secrecy. Thus, the tasks of this article are to track trueness of a human being in its secrecy in a secret $\mathrm{s} / \mathrm{p}(\mathrm{l})$ aces; attract attention to strangeness, postfreakness, realizing in a secret $\mathrm{s} / \mathrm{p}(\mathrm{l})$ aces and compare mysterious and secrecy of $\mathrm{s} / \mathrm{p}(\mathrm{l})$ atiality of a postman.

An explanation of this is found, when one of the characters of Women in Love by David Herbert Lawrence explains his views on the future of humanity on the island as a secret $\mathrm{s} / \mathrm{p}(\mathrm{l})$ ace. He ponders, that human beings are like gall-apples, balls of bitter dust «because they won't fall off the tree when they're ripe. They hang on to their old positions when the position is over-past, till they become infested with little worms and dry-rot» [Lawrence, 1920]. Mankind as a particular expression of the incomprehensible is completed and done and now humanity is unclaimed, failed to reach its address letter, dead letter of law and, hence, a mistake. That is why «one should just live anywhere - not have a different place» [Lawrence, 1920] despite the fact that nature doesn't care whether a self will live at all. Thus, David Herbert Lawrence's vitalism is drawing closer to Levi R. Bryant's vital realism or David Roden's speculative posthumanism as trends in speculative realism. In this case, a secret place of posthuman is nothing but a secret $\mathrm{s} / \mathrm{p}(\mathrm{l})$ ace.

In the film $A W$ alk to Remember by Adam Shankman, based on the novel by Nicholas Sparks, also one can see a water reservoir and surrounding lake as a secret $\mathrm{s} / \mathrm{p}(\mathrm{l})$ ace. But more impressive secret $\mathrm{s} / \mathrm{p}(\mathrm{l})$ ace is a border between two States, on which a human being appears in two $\mathrm{s} / \mathrm{p}(\mathrm{l})$ aces at once. A secret $\mathrm{s} / \mathrm{p}(\mathrm{l})$ ace as a moving place reveals itself through not only water or air but also the earth. A list of elements, related to a secret $\mathrm{s} / \mathrm{p}(\mathrm{l}) \mathrm{ace}$, is supplemented. According to Gaston Bachelard, it is extremely important to comprehend elementary of any kind of place, but an urban place lacks of elements, which induces a nature as a stranger. He signs a secret and directly experienced space as a shell, which can be correlated with a fold of subjectivity according to Gilles Deleuze.

In a certain sense city lacks such places as shells, folds of subjectivity, but full of dangerous non-places, Marc Augé notices. In both cases expectations of adventures, events take place. Even if it is not an airplane salon or a departing ship, it's always moving places and this abolishes a place itself, but at the same time establishes it. However, in the case of a secret place, the companion is a friend as the innermost otherness, hither alterity. And if a lonely aimless stranger best describes a place, then given the place a face creates it. Loneliness in a secret place must be divided into true autism, using the terminology of A. Kirby, in comparison with the narcissism of non-place, which, as Marc Augé observes, conformism for the sake of authenticity. Besides, if Michel de Certeau understands space as non-place than Marc Augé as moving place with a discourse, i. e. a space and relation to it and in a certain case space is places of surveying.

In a novel Alessandro Baricco The Young Bride, one of the characters considers a lake in the dull countryside, which has no name and is rumored to not even exist, as a the secret $\mathrm{s} / \mathrm{p}(\mathrm{l})$ ace. In this case, the secret $\mathrm{s} / \mathrm{p}(\mathrm{l})$ ace is supplemented by secret time, when birds with other horizons reflected in their feathers devoured insects with a silvery rustling. These happens only if someone looked at the birds and then «every slither of the yellow feathers over the water offered the spectacle of a successful passage of Creation. Or, if you like, the magical opposite of a Creation that hadn't happened, that is a detail that had escaped the otherwise random genesis of things, an exception to disorder and senselessness. In any case, a miracle» [Baricco, 2016]. Looking at birds distracted even from the elegance of sunset, merging with nature as an accomplice in strangering, being captured by the event that confers secrecy to the $\mathrm{s} / \mathrm{p}(\mathrm{l})$ ace itself. «The yellow-feathered birds disappeared into a distance of which only they possessed 
the secret, the countryside returned to being obvious, as it was, and the lake mute as they had found it» [Baricco, 2016]. So, it happens not only in a place but in a space as a distance too and this indicates at the same time conjunction and disjunction of secret place and surrounding space as its contexts.

Alessandro Baricco demonstrates that a secret s/p(l)ace needs a secret human, or better human, or even better posthuman or the best thing postman as scriptor. It happens due to stratified sum, stratigraphic time according to G. Deleuze, of writing and living in a fleeting splendor. "At most I could not remember certain sentences exactly: but it should also be said that, in bringing them back to the surface, from the place where they had drifted, I ended up rewriting them, in my mind, in a form very close to the original but not identical, the result being a sort of blurring or echo, or doubling, in which what I imagined I had written developed, splendidly» [Baricco, 2016]. Episodes of his writing are often wedged into the novel, but it is hardly worth identifying the described novelist with Alessandro Baricco himself. Claiming that everything that is not written is lost and not named is unnerved just like a lake without a name is lost and unnerved, at the same time this novelist acknowledges that the beginning of any story reveals an animal movement of a body.

If in The Young Bride the non-present groom becomes not a feeling, but an initial and saving s/p(l)ace for the two of them, then communication with another man becomes a secret $\mathrm{s} / \mathrm{p}(\mathrm{l})$ ace. They turned out to be in a fold of creation or subjectivation as a crack in the world, into which this man had expelled himself, stolen from a devastation in linguisterical spell. However, usually in pieces of art, the $\mathrm{s} / \mathrm{p}(\mathrm{l})$ ace for two is loneliness, and secrecy to this $\mathrm{s} / \mathrm{p}(\mathrm{l})$ ace gives just the possibility to share this loneliness. This issue in a perspective of relationship is explored in The Secret Place by Tana French. In this novel, two types of a secret s/p(l)aces are compared. One of them is a noticeboard in an elite school for girls, where they like to reveal their secrets. Another one is a cypress glade as a fold of own true reality, where girls hold into wild birds themselves and hold one another by wings. In both cases, childhood and youth, friendship and love, when a human being is the most real, are the main secret. One of the landscape photos, pinned on the noticeboard, had such a caption «I tell everyone this is my favourite place 'cause it's cool $\langle\ldots\rangle$ This is my actual favourite place 'cause no one here knows I'm supposed to be cool» [French, p. 44].

In this context, the practice of creating «little secrets» by post-Soviet girls is worth mentioning. In the usually greened courtyards of new buildings, there was a secluded s/p(l)ace in which a hole was pulled out. In this hole, attractive plant fragments supplemented with colored glass, obsolete or even favorite bijouterie and so forth were s/p(l)aced. The «little secret» was covered with a piece of transparent glass from above and filled up with earth again. Usually the girls knew well the s/p(l)ace and contents of each other «little secrets», but they were only rarely shown to the boys. Such a «little secret» was obviously a metaphor of virginity with pronounced chthonic implication and its opening - of defloration, literally, the appearance of the flora and vitality in it. So, given the dense population of residential areas, the girls still found the opportunity to create «little secrets» as a secret $\mathrm{s} / \mathrm{p}(\mathrm{l})$ aces.

In a secret $\mathrm{s} / \mathrm{p}(\mathrm{l})$ ace things seem clean, bright and free from any danger as a miracle, which is different every time and changes every present human being. All another world is concentrates on unbearable reality and disappears and every minute contains a million years. Young lovers getting used to the shapes of the glade perfectly and «in that instant it's him, the same guy whose texts she's cupped in her hands like fireflies» [French, p. 174]. So, again, the vital and the textual are intertwined in a secret.

In a certain sense, a body is forgetting, losing and disappearing as Bryan S. Turner argues: «secular technological changes to embodiment will of course transform the body; they will also radically transform society and so the post-body will also include post-social» [Turner, p. 15]. However, in another sense, postbody is appearing although synechdochically. So, it's a non-presence of a body according to Timothy Morton. 
Choice of post-bodies have always done in a «post-places $\langle\ldots\rangle$, where things had always already happened» [Ureczky, p. 173]. If Roland Barthes he justifies that a love choice has always been done, then Eszter Ureczky justifies the always done the choice of postbody in the posts/p(l)ace. On a showcase of Pál Adrienn of Ágnes Kocsis she investigates irreversibly deteriorating bodies the dystopical gate between life and death in the hospital. It's close, but certainly not humanized space, so after Yi-Fu Tuan not a place at all. The character of this film, whose job as a nurse is to touch others, untouchable herself because she's too fat. Moreover, «she rather appears like an amoral creature for whom the ideas of freedom and sin do not even exist» [Ureczky, p. 180]. So postbody is pictured by synechdocha and grotesque, postfreakily including human and nonhuman elements as isomorphism in the understanding of Elizabeth Grosz suggests.

This character reverted her body in a forest secret $\mathrm{s} / \mathrm{p}(\mathrm{l})$ ace on a fresh air, which is the most important metaphor of freedom in another film of Ágnes Kocsis's, Fresh Air. In this film a contrast to too claustrophobic in Eve Kosofsky Sedgwick's sense closet is the high entry deserted bridge as a real secret $\mathrm{s} / \mathrm{p}(\mathrm{l})$ ace, where enough not only air but also water not only for freedom but also for love. On this occasion Nóra Séllei notes, that observable closet «This paradoxically means that what is inhabited by her as her own space is actually a space that creates a unique isomorphism with her body inasmuch as she is turned into a sexualized object exposed to and on display for the public» [Séllei, p. 245]. Red and purple colors of the closet as a space of all too human body, post-body of a flying mermaid in natural colors resist through slipping away from the inside out both teleology and homeliness.

Not only lavatory but also bedroom can be explored as a claustrophobic closet. The showcase of it is a project of Carlo Mollino Bedroom for a Farmbouse in the Rice Fields (1943). This was a shell paper architecture the project, materialized only temporarily and partly. But its materials are made tangible, juxtaposing of soft textures on the floors, walls, curtains, and bed and thus intensifying the sense of touch. Carlo Mollino followed the thought of Paul B. Preciado, regarding cabinet, capsule, cocoon or cabin as a cell for the senses. It was a dream about flying secret s/p(l)ace and a flyer in the bed looking into the mirror. «The ritual of going to bed seems to gain extra meaning. The last step in the process of getting ready for bed is to look into the mirron» [Verhaeghe, p. 6]. In this the most intimate place in space the flyer saw a woman like himself and so his loneliness eventuated narcissistically, but he considered this option the most successful for avoiding boredom in the bedroom.

According to Georges Teyssot, spatial boredom is a stabilization of pleasure in the habitual and comfortable and the void is a pure possibility, and a counter of a form. Aleksandra Gordowy even uses a concept of the good banality. She suggests, «the interiority elaborated and redefined within the design of the apartments, as a principle uses the notion of empty/full, disappearance and reappearance. The design elements are the folding, sliding and pivoting walls, where the furniture is held "in-between" them. The dynamic and the use of the space changes together with the inhabitant interacting with those walls. Consequently, the multiplicity of spaces is created, and the furniture holds the function of mediators between them» [Gordowy, 2017]. It is so supposed to accept at the same time boredom and to avoid it. As Christian Parreno notes after Roland Barthes, if boredom is a bliss from the side of pleasure then it is a space of uncertainty and latency, in-between $\mathrm{K}$. Barad, with a deficit of meaning. "The space mediating boredom and desire resonates with metaphors of voids in antiquity, equally related to the experience of love and to the origins of life» [Parreno, 2017, p. 21]. Thus, a secret s/p(l)ace can be a space of avoiding entertainment and freak out as acting out, using in Lacanian concept.

In a similar vein, Steve Pile discerns a secrecy of a place in unconscious desires. «Indeed, the existence of an unconscious, the vicissitudes of desire, the secret life of things (for example, phallus-shaped) and the slippages of meaning, and the hiding and inadvertent expression of innermost feelings are often implicit in our common-sense understandings of ourselves» [Pile, 1996, p. 7]. In many cases, the whole city may turn out to be a kind of closet or 
bedroom at the same time and flâneur, drifter appears as a secret spectator, providing an appropriate degree of extimacy.

When exploring a secret $\mathrm{s} / \mathrm{p}(\mathrm{l})$ ace, it is especially appropriate to use psychogeography, psychoanalytical psychogeography in particular. In this regard, it would be appropriate to mention the famous expression of Antoine de Saint-Exupéry «It is such a secret place, the land of tears». Virginia L. Blum and Anna J. Secor note, that «trauma works to fold both space and time» [Blum \& Secor, 2014, p. 104] and then space unfold in repetition on both consciousness and unconsciousness converging scenes. So trauma is not so topographical but rather topological in Lacanian sense and metaphorize through nonobvious spatial models: «topology has pushed the cultural limits of our sensorium $\langle\ldots\rangle$ the apparent movement of figures on a spinning zoetrope» [Blum \& Secor, 2014, p. 114]. Garber Marjorie develops this topic regarding to body or, more precisely, postbody in a sex and gender aspects. "The history of architecture over the last four hundred years has been a history of consistent negotiation between public and private spaces, indoor and outdoor, secret and open, male and female» [Garber, 2000, p. 98]. However, in a house, the differences are between two, in the vein of correlation man with the 'head', but a woman is its 'heart'. However, there is also differance not only within a house but also within a city, body-city, using the concept of Elizabeth Grosz. «Sexual secrets become sexual zones. This secret of adult sexuality - which ultimately involves confining the spaces of sexuality, in other words, putting it behind doors of various sizes and shapes entails another kind of spatial dislocation, the divergence of the signifier from the signified, the felt loss of presence - of desire from its object, of words from meaning, of form from content» [Blum, 1998, p. 205]. So, domestic and urban secrets seep through the architecture with secretion and, accordingly, are revealed, while the secret $\mathrm{s} / \mathrm{p}(\mathrm{l})$ ace remains its mysteriousness.

Jane Jacobs assumes «The way to get at what goes on in the seemingly mysterious and perverse behavior of cities is, I think, to look closely, and with as little previous expectation as is possible, at the most ordinary scenes and events, and attempt to see what they mean and whether any threads of principle emerge among them» Jacobs, 1961, p. 13]. She substantiates a thought, that a structural secrets precisely ensure diversity. «So long as we are content to believe that city diversity represents accident and chaos, of course, its erratic generation appears to represent a mystery» [acobs, 1961, p. 150]. Therefore, secret $\mathrm{s} / \mathrm{p}(\mathrm{l})$ ace is often found in suburbia or abandoned, but rectilinear streets with the horizon as a fragment of sky between the many buildings lack a mystery. Thus, she also problematizes a very important context of this topic issue of differance between a secret and a mystery.

Jean Baudrillard considers even a mystery as an artificial, objectified in comparison with a truth and therefore transparent like an evil. However, from a position of object-oriented ontology it rather an advantage of a mystery of, for example, a strange stranger according to Timothy Morton. Steve Pile also ponders «the stranger is still an ambiguous figure, but the social interactions have changed subtly» [Pile, 1999, p. 24]. He after Steve Hinchliffe considers nature as a stranger too and finds a mysterious place in "sweet suburbia", where a natural mystery is a requisite for a secret of a human being.

A secret $\mathrm{s} / \mathrm{p}(\mathrm{l})$ ace in suburbia allows eluding an urban alienation as well as a full absence of a secret in a village including a global village. Therefore, Steve Pile continues considerations of Roger Silverstone about a spatiality of the creative and destructive impulses, the paradox of ordered disorder. In a similar vein, Ash Amin and Stephen Graham ponder about a spatiality of connection and disconnection within and between cities. So, sometimes a whole city may be regarded as a secret $\mathrm{s} / \mathrm{p}(\mathrm{l})$ ace, for example in a case, when it is a city located outside the usual traveling rout. But even a capital may be a secret $\mathrm{s} / \mathrm{p}(\mathrm{l})$ ace if it's functionally disconnected from flows of power and influence but has a saturated own eventuality instead: «spaces which are physically close within a city can simultaneously be relationally very distant and relatively disconnected» [Amin \& Graham, 1999, p. 11]. More widely, it is apparently correlated with a problem of human-nonhuman disconnection in the context of David Roden's speculative posthumanism. On the other hand, considerations about functional connection and 
disconnection display that not only spatiality of philosophical concepts variations and art sensations varieties but also philosophical concepts variations and scientific functions variables intersect and intertwine, creating conceptual secret $\mathrm{s} / \mathrm{p}(\mathrm{l})$ aces.

In this regard, it is appropriate to mention Bernard Tschumi's conception of architectural disjunction. After Walter Benjamin and Henry Lefebvre, he insists, that places are too mystified by the power groups that implement it. «Ex-centric, dis-integrated, dis-located, dis-juncted, deconstructed, dismantled, disassociated, discontinuous, deregulated... de-, dis-, ex-. These are the prefixes of today. Not post-, neo-, or pre-» [Tschumi, 1996, p. 225]. Thus obviously prefers secret to a mystery and highly appreciates its resistential potential. «Yet architecture is inhabited: sequences of events, use, activities, incidents are always superimposed on those fixed, spatial sequences. These are the programmatic sequences that suggest secret maps and impossible fictions, rambling collections of events all strung along a collection of spaces, frame after frame, room after room, episode after episode» [Tschumi, 1996, p. 157].

In conclusion, it is worth to refer to considerations of Jacques Derrida, who most often reveals a secret place in literature, about one of the architectural projects of Bernard Tschumi. He inquires and gives definitely a negative answer: «Let us not elude the question: if this configuration presides over what in the West is called architecture, don't these follies wipe the slate clean? Don't they lead back to the desert of an architecture, to a degree zero of architectural writing where this writing would lose itself, henceforth without telos, without aesthetic aura, without grounding, without hierarchical principle, without symbolic signification, in short a prose made up of abstract, neuter, inhuman, useless, uninhabitable, and meaningless volumes? Precisely not. The "follies" affirm; they commit their affirmation beyond this ultimately annihilating, secretly nihilistic repetition of metaphysical architecture» [Derrida, 2008, p. 93]. In Deleuzian vein thus plan of composition framed too tender flesh of madness, «follies» and sets up secret $\mathrm{s} / \mathrm{p}(\mathrm{l})$ aces of inhuman or, more precisely in this case, posthuman. This is a cinder of $\mathrm{s} / \mathrm{p}(\mathrm{l})$ ace as a sense, in Jacques Derrida's words «secret of mystery» of it or, according to Luce Irigaray a place of place. Developing a deconstructivist approach to a place, Joseph Hillis Miller conceptualizes presence without place, comparable with the non-presence of Timothy Morton. This is possible for such a place resists to topography, topology, and toponymy and is a secret $\mathrm{s} / \mathrm{p}(\mathrm{l})$ ace as place-without-place due to its posthumanity.

\section{REFERENCES}

Amin, A., \& Graham, S. (1999). Cities of Connection and Disconnection. In J. Allen, D. Massey \& M. Pryke (Eds.), Unsettling Cities: Movement/Settlement (pp. 7-53). London: Routledge in association with The Open University.

Baricco, A. (2016). The Young Bride. New-York: Europa Editions.

Blum, V. L., \& Secor, A. J. (2014). Mapping Trauma: Topography to Topology. In P. Kingsbury \& S. Pile (Eds.), Psychoanalytic Geographies (pp. 103-116). Farnham: Ashgate.

Blum, V. L. (1998). Ladies and Gentlemen: Train Rides and Other Oedipal Stories. In H. Nast \& S. Pile (Eds.), Places Through the Body (pp. 197-209). London: Routledge.

Böhme, G. (1993). Atmosphere as a Fundamental Concept of a New Aesthetics. Thesis Eleven, 36, 113-126. DOI: https://doi.org/10.1177/072551369303600107.

Cresswell, T. (2004). Place: A Short Introduction. Malden, MA: Blackwell Pub.

Deleuze, G., \& Guattari, F. (1994). What Is Philosophy? (H. Tomlinson \& G. Burchell, Trans.). New York: Columbia University Press. (Original work published 1807).

Derrida, J. (2008). No (Point of) Madness - Maintaining Architecture. In J. Derrida, Psyche Inventions of the Other (Vol. II, pp. 87-103). (P. Kamuf \& E. G. Rottenberg, Eds.). Stanford: Stanford University Press.

Fiedler, L. (1978). Freaks: Myths and Images of the Secret Self. New-York: Simon and Schuster.

French, T. (2014). The Secret Place. New York: Viking Penguin. Retrieved from https://issuu.com/pdfparadise2/docs/the-secret-place-pdf.

Garber, M. (2000). Sex and Real Estate: Why We Love Houses. New-York: Pantheon. 
Gordowy, A. (2017). The Good Banality and the Pleasure of Boredom. Retrieved from https://repository.tudelft.nl/islandora/object/uuid\%3A26f24ae2-b76f-4549-bbc3$8 \mathrm{c} 78 \mathrm{c} 0 \mathrm{e} 16 \mathrm{dba}$.

Jacobs, J. (1961). The Death and Life of Great American Cities. New York: Random House.

Lawrence, D. H. (1920). Women in Love. Retrieved from https://issuu.com/rbof/docs/women_in _love_-_part_1 \& https://issuu.com/rbof/docs/women_in_love_-_part_2.

Parreno, Ch. (2017). Boredom and Desire. AArchitecture, 33, 20-21. Retrieved from https://issuu.com/aaschool/docs/aarchitecture33.

Pile, S. (1996). The Body and the City. Psychoanalysis, Space and Subjectivity. London: Routledge.

Pile, S. (1999). The Heterogeneity of Cities. In S. Pile, C. Brook \& G. Mooney (Eds.), Unruly Cities? Order/disorder (pp. 6-48). London \& New York: Routledge in association with The Open University.

Séllei, N. (2018). Space, Body and Subjectivity in Ágnes Kocsis’s Film, Fresh Air (2006). In A. Staub (Ed.), The Routledge Companion to Modernity, Space and Gender (pp. 238-249). New York: Routledge. DOI: https://doi.org/10.1201/9781315180472-17.

The Grus. (2020, November 1). A Secret Place. Retrieved from https://thegrus.bandcamp.com/tra ck/a-secret-place.

Tschumi, B. (1996). Architecture and Disjunction. Cambridge, MA \& London: The MIT Press.

Turner, B. S. (2012). Introduction. The Turn of the Body. In B. S. Turner (Ed.), Routledge Handbook of Body Studies (pp.1-17). New York: Routledge. DOI: https://doi.org/10.4324/9780203842096.

Ureczky, E. (2016). Post-Bodies in Hungarian Cinema: Forgotten Bodies and Spaces in Ágnes Kocsis' Pál Adrienn. In A. Virginás (Ed.), Cultural Studies Approaches in the Study of Eastern European Cinema: Spaces, Bodies, Memories (pp. 168-191). Cambridge: Cambridge Scholars Publishing.

Verhaeghe, G. (2017). Self-Portrait in Bed. A Case Study of Carlo Mollino's "Bedroom for a Farmhouse in the Rice Fields". In Proceedings from International and Interdisciplinary Conference IMMAGINI? Image and Imagination between Representation, Communication, Education and Psychology, Brixen, Italy, 27-28 November, 2017. DOI: https://doi.org/10.3390/proceedings1090894.

\section{Zahurska Nataliia V.}

DSc in Philosophy, Professor of the Department of Theoretical and Practical Philosophy named after Professor J. B. Schad

V. N. Karazin Kharkiv National University

6, Svobody sqr., 61022, Kharkiv, Ukraine

E-mail: zagurskaya@karazin.ua

ORCID: http://orcid.org/0000-0001-5142-8064

Article arrived: 10.11 .2020

Accepted: 27.11.2020

\section{ПОСТАЮАИНА В СЕКРЕТНОМУ МІСЦІ/ТІ}

\section{Загурська Наталія Віталіївна}

Аокторка філософських наук, професорка кафелри теоретичної і практичної філософії імені професора Й. Б. Шаца

Харківський національний університет імені В. Н. Каразіна

м. Свободи, 6, Харків, 61022

E-mail: zagurskaya@karazin.ua

ORCID: http://orcid.org/0000-0001-5142-8064 
У статті АосліАжено постгуманістичні аспекти проб̆леми секретного місця/та, тобто водночас і простору, і місця. Проведена Аиференціація простору і місця, секрету і таємниці. АосліАжено різноманітність уявлення про секрет (потаємність, завуальованість, зашифрованість тощо) віА тенденції ретельно зберігати секрет місця/та до вимоги повністю демістифікувати місце. Філософія, особливо філософська антропологія, у цьому разі постає геофілософією, географією мюдини. Отже, концептуалізуюча АюАська істота оглядається у фікії, Аружбі з мандшафтом, місцем/том. Продемонстровано значення природних стихій (вода, повітря, вогонь тощо) Аля секретного місця/та. Особливу актуальність цьому АосліАженню наАає звернення до поточної концепції атмосфери, яка слабко сприймається, але є впливовою. Простежено взаємозв'язок між секретним місцем/том і секретною особою, як-от фрік, Секретний Санта тощо. Проведене розрізнення секретного місця/та і не-місця як місця, що рухається з Аискурсом, місця оглядання. Показано важливість секретного місця/та Аля формування пост-тіла в ситуації, коли тіло як таке $є$ втраченим. Продемонстровано важливість психоаналітичної та психогеографічної концептуалізації секретного місця/та. Ао них примикає розгляА простору щодо нудьги як стабілізації задоволення у звичному та зручному, хороша банальність, насолода з боку задоволення. Значення секретного місця/та стверАжується в умовах, коли місто відіграє не лише кон'юнктивну, сполучну, але й Аиз'юнктивну, роз'єАнавчу роль. Зроб̆лено висновок про секретне місце/то як постАюАське місце місця, місце-без-місця 3 таємницею секрета. АосліАження проведено на матеріалі актуальної культури (Аітератури, кіно, архітектури, Аизайну тощо), а також життевих практик. Це віАповіАає Аелезіанському твердженню про перетин поняття, проспекту та афекту. Ао АосліАження також залучені спекулятивний реалізм, спекулятивний постгуманізм та інші пов'язані з проблематикою статті концепції.

Ключові слова: секретне місце/то, простір, місце, постАюдина, АюАська істота.

Стаття надійшла до редакції: 10.11.2020

Схвалено Ао Аруку: 27.11.2020 